\title{
Breath hydrogen response to lactulose in healthy subjects: relationship to methane producing status
}

\author{
D Cloarec, F Bornet, S Gouilloud, J L Barry, B Salim, J P Galmiche
}

\begin{abstract}
In order to assess the relationship between methane $\left(\mathrm{CH}_{4}\right)$ producing status and the breath excretion of hydrogen $\left(\mathrm{H}_{2}\right)$ in healthy subjects, breath $\mathrm{CH}_{4}$ and $\mathrm{H}_{2}$ were simultaneously measured for 14 hours after oral ingestion of $10 \mathrm{~g}$ lactulose in 65 young volunteers. Forty were breath $\mathrm{CH}_{4}$ producers and 25 were not. Statistically significant differences were observed between both groups, with lower values for $\mathbf{C H}_{4}$ producers recorded for the following parameters: fasting basal value of breath $\mathrm{H}_{2}(8.1$ (4.9) $v 5.2$ (3.7) ppm, p<0.05), mouth-to-caecum transit time (68 (24) $v 111$ (52) $\mathrm{min}, \mathrm{p}<0.005$ ), and breath $\mathrm{H}_{2}$ production measured as area under the curve 13.1 (6.9) $v$ $\left.8.8(3.8) 10^{3} \mathrm{ppm} / \mathrm{min}, \mathrm{p}<0 \cdot 02\right)$. There was no significant correlation between individual production of breath $\mathrm{H}_{2}$ and $\mathrm{CH}_{4}$. These results indicate that the response to lactulose depends on breath $\mathrm{CH}_{4}$ producing status. In clinical practice, defining normal values of mouth-tocaecum transit time without knowledge of breath $\mathrm{CH}_{4}$ producing status may lead to misinterpretation of the $\mathrm{H}_{2}$ breath test.
\end{abstract}

The hydrogen $\left(\mathrm{H}_{2}\right)$ and methane $\left(\mathrm{CH}_{4}\right)$ produced in the human body derive entirely from colonic anaerobic bacterial fermentation. While most of these gases are consumed on site or excreted in flatus, the part expelled by the lungs can be easily collected and measured by endexpiratory sampling. ${ }^{12} \mathrm{H}_{2}$ production increases when a fermentable carbohydrate is incompletely absorbed in the small intestine, forming the basis for the use of the $\mathrm{H}_{2}$ breath test. This non-invasive procedure has been extensively used in clinical practice ${ }^{3-11}$ and pharmacological studies $^{12}$ to measure mouth-to-caecum transit time. It has also been proposed as a semi quantitative method for evaluating intestinal malabsorption of carbohydrates. ${ }^{1314}$ The recent development of a simple gas analyser not only offers the opportunity to measure breath $\mathrm{H}_{2}$ but breath $\mathrm{CH}_{4}$ as well. Although the substrates for $\mathrm{CH}_{4}$ production are not yet fully identified, ${ }^{215}$ it has been shown that in Caucasian adults, only $30 \%-50 \%$ are breath $\mathrm{CH}_{4}$ producers, whereas $90 \%-98 \%$ excrete breath $\mathrm{H}_{2}{ }^{16-22}$ In most previously published investigations, however, little attention has been paid to the relationship between breath $\mathrm{CH}_{4}$ producing status and the $\mathrm{H}_{2}$ excretion profile after lactulose administration. In a previous study evaluating starch malabsorption of pasta, ${ }^{23}$ we observed different patterns of $\mathrm{H}_{2}$ production according to breath $\mathrm{CH}_{4}$ producing status, a finding which has also been described in preliminary studies by other authors. ${ }^{162+24}$ This prompted us to prospectively assess the relationship between breath $\mathrm{CH}_{4}$ producing status and the breath excretion of $\mathrm{H}_{2}$ in healthy subjects.

\section{Methods}

\section{SUBJECTS}

Sixty five subjects ( 32 men, 33 women) ranging from 19 to 30 years (mean $22 \cdot 4(2)$ ) were selected from a population of healthy volunteers without known disease and free from gastrointestinal symptoms as previously tested in our laboratory. In addition, their breath $\mathrm{CH}_{4}$ producing status was already known. Forty were breath $\mathrm{CH}_{4}$ producers as defined below. Their breath samples were compared with those of 25 healthy controls who were breath $\mathrm{CH}_{4}$ non-producers. All volunteers were French born Caucasians of similar ethnic origin. As enemas, laxatives, and antibiotics can affect the colonic microflora and, hence, the production of intestinal gas, ${ }^{25}$ any individual receiving these treatments within three months before the study was excluded. All subjects gave their informed consent to the study protocol which had been approved by the Ethics Committee of our hospital.

STUDY DESIGN AND BREATH ANALYSIS The effect of a single orally administered of $10 \mathrm{~g}$ lactulose (Duphalac ${ }^{\circledR}$, Duphar Laboratories, Villeurbanne, France) dissolved in $100 \mathrm{ml}$ cold water was studied for 14 hours in the 65 selected subjects for breath $\mathrm{H}_{2}$ and $\mathrm{CH}_{4}$ production. The evening meal preceding the morning lactulose test was standardised to contain a low level of indigestible material ${ }^{26}{ }^{27}$ and consisted of fish, white rice, and a soft cheese; water was freely permitted. After a 12 hour fasting period, the lactulose test was performed at 0900 hours after suitable oral hygiene (careful mouthwashing with a $1 \%$ chlorhexidine solution; Givalex ${ }^{\circledR}$, Norgan Laboratories, Paris, France) to reduce oropharyngeal microfloral activity. ${ }^{28-30}$

Breath samples were collected at 15 minute intervals for 30 minutes before lactulose ingestion, every 10 minutes for the first two hours, and then every 15 minutes for the next 12 hours thereafter. During the test, subjects were forbidden to eat, smoke, or take exercise. ${ }^{28}$ Alveolar air samples were obtained after a normal inspiration, by having the subjects exhale through a mouthpiece into two bags connected by a three-way valve. When the first $500 \mathrm{ml}$ expiratory air filled one plastic bag, the end alveolar air was then collected in a secorid bag (1-1 rubber anaesthesia bag adapted with a one way valve). The end alveolar air was then immediately transferred into $50 \mathrm{ml}$ plastic 
TABLE $\mathrm{CH}_{4}$ producing status and results of $\mathrm{H}_{2}$ breath test in healthy subjects

\begin{tabular}{|c|c|c|c|}
\hline & $\begin{array}{l}\mathrm{CH}_{4} \text { non-producers } \\
(n=25)\end{array}$ & $\begin{array}{l}\mathrm{CH}_{4} \text { producers } \\
(n=40)\end{array}$ & $\begin{array}{l}\text { Total } \\
(n=65)\end{array}$ \\
\hline Age (yrs) & $22 \cdot 7(0 \cdot 9)$ & $22 \cdot 3(1 \cdot 7)$ & $22 \cdot 4(1 \cdot 7)$ \\
\hline $\operatorname{Sex}(M / F)$ & $15 / 10$ & $17 / 23$ & $32 / 33$ \\
\hline Fasting basal $\mathrm{H}_{2}$ concentration (ppm) & $8 \cdot 1(4 \cdot 9)^{\star}$ & $5 \cdot 2(3 \cdot 7)$ & $6 \cdot 3(4 \cdot 4)$ \\
\hline $\mathrm{H}_{2}$ non-producers $(\mathrm{n})$ & & 4 & \\
\hline Mouth-to-caecum transit time (min) & $68(24) \dagger$ & $111(52)$ & $94(47)$ \\
\hline Delta $\mathrm{Max} \mathrm{H}_{2}$ (ppm) & $60(41)$ & $46(23)$ & $52(32)$ \\
\hline Time of $\mathrm{H}_{2}$ peak ( $\mathrm{min}$ ) & $180(80)$ & $209(98)$ & $197(92)$ \\
\hline $\mathrm{H}_{2}$ production $\left(10^{3} \mathrm{ppm} / \mathrm{min}\right)$ & $13 \cdot 1(6 \cdot 9) \ddagger$ & $8 \cdot 8(3 \cdot 8)$ & $10 \cdot 6(5 \cdot 7)$ \\
\hline \multicolumn{4}{|l|}{ Time for $\mathrm{H}_{2}$ return to basal } \\
\hline concentration $(\min )$ & $564(178)$ & $573(137)$ & $569(154)$ \\
\hline Duration of $\mathrm{H}_{2}$ production (min) & $495(177)$ & $462(120)$ & $476(146)$ \\
\hline $\mathrm{H}_{2}$ concentration at $840 \mathrm{~min}(\mathrm{ppm})$ & $4 \cdot 9(3 \cdot 2)$ & $3 \cdot 0(2 \cdot 1)$ & $3 \cdot 8(2 \cdot 8)$ \\
\hline
\end{tabular}

Results are expressed as mean (SD). See Methods for definition of $\mathrm{CH}_{4}$ producing status. ${ }^{\star} \mathrm{p}<0.05 v \mathrm{CH}_{4}$ producers; $\nmid \mathrm{p}<0.005 v \mathrm{CH}_{4}$ producers; $\ddagger \mathrm{p}<0.02 v \mathrm{CH}_{4}$ producers.

syringes fitted with two way stopcocks, and analysed within a two hour period.

The $\mathrm{H}_{2}$ and $\mathrm{CH}_{4}$ concentration in breath samples were determined simultaneously with a Micro Lyzer DP gas chromatograph (Quintron Instrument Company, Milwaukee, WI) using a molecular sieve column (12' Hysep Q, 60/80 mesh). Dry air was used as the carrier gas at a flow rate of $40 \mathrm{ml} /$ minute. The chromatograph was calibrated with a $\mathrm{H}_{2}$ and $\mathrm{CH}_{4}$ reference mixture in compressed air (Quingas ${ }^{\circledR} 2$ ). Results were expressed as parts per million $(1 \mathrm{ppm}=$ approximately $0.05 \mu \mathrm{mol} / 1$ for $\mathrm{H}_{2}$ and $\left.\mathrm{CH}_{4}\right)$. For both gases, the smallest detectable concentration was $2 \mathrm{ppm}$ with a linear accuracy response range of 2-150 ppm.

Breath $\mathrm{CH}_{4}$ concentrations were taken as the difference between the result of a breath sample and the room air concentration; breath $\mathrm{CH}_{4}$ producing status was defined as a mean $\mathrm{CH}_{4}$ breath sample concentration greater than $2 \mathrm{ppm}$ above that in ambient air. This criterion was based on the sensitivity and reproducibility of the method used.

The fasting breath $\mathrm{H}_{2}\left(\mathrm{FBH}_{2}\right)$ and $\mathrm{CH}_{4}$ $\left(\mathrm{FBCH}_{4}\right)$ concentrations used were the mean of the three samples before lactulose ingestion. Breath $\mathrm{H}_{2}$ producing status was defined as the ability of a subject to produce an increase in breath $\mathrm{H}_{2}$ of greater than $20 \mathrm{ppm}$ above baseline values $\left(\Delta \mathrm{H}_{2}\right)$ at one or more breath collections after lactulose ingestion. ${ }^{331}$ An early $\mathrm{H}_{2}$ peak was

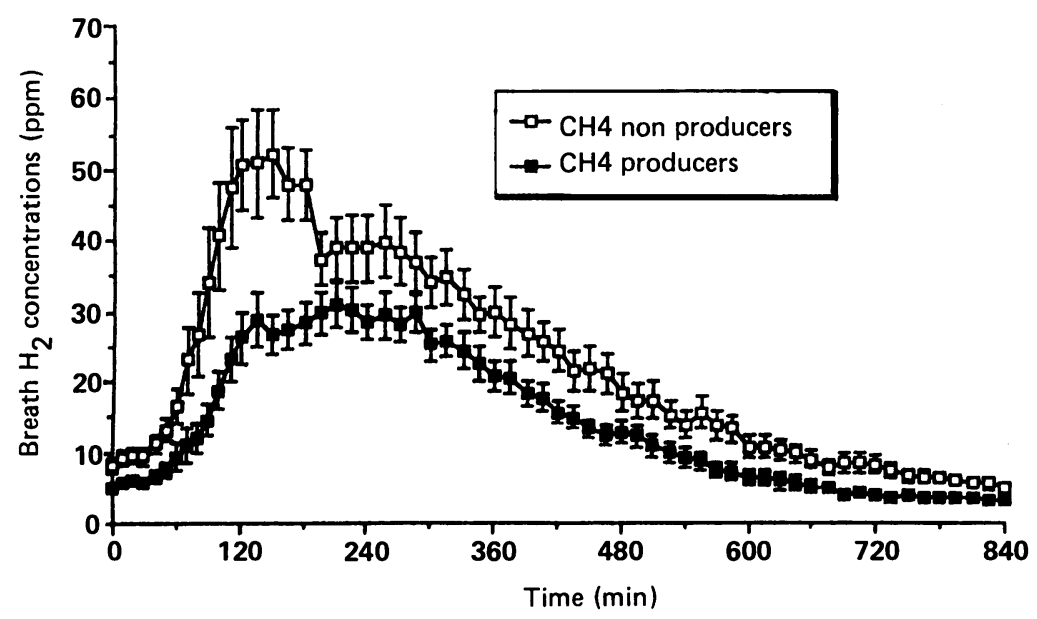

Figure 1: Breath $\mathrm{H}_{2}$ concentrations (mean (SEM)) in $\mathrm{CH}_{4}$ non-producers $(n=25)$ and producers ( $n=36 ; 4 \mathrm{CH}_{4}$ producers not represented after failing to produce $\mathrm{H}_{2}$ ) after oral administration of $10 \mathrm{~g}$ lactulose. defined as an increase of $\mathrm{H}_{2}$ greater than $5 \mathrm{ppm}$ above $\mathrm{FBH}_{2}$ before the first 30 minutes. ${ }^{30}$ Mouth-to-caecum transit time was defined as the time from the beginning of lactulose intake until the period just before the initial increase above fasting levels of $10 \mathrm{ppm}$ or more $\mathrm{H}_{2}$ where this increase was sustained. ${ }^{+10}$ As the phase of the menstrual cycle (luteal $v$ progestational phase) has been shown to modify the duration of the mouth-to-caecum transit time, ${ }^{11}$ this variable was studied in each woman.

Breath $\mathrm{CH}_{4}$ production was estimated as the area under the curve (AUC) between 0 and 840 minutes; in breath $\mathrm{H}_{2}$ and $\mathrm{CH}_{4}$ producers, the AUC for $\mathrm{CH}_{4}$ were determined before the lactulose had reached the caecum at time (ti) (corresponding to the mouth-to-caecum transit time) and for the same time thereafter.

\section{STATISTICAL ANALYSIS}

Results were expressed as means (SD) with the exception of the figures (means (SEM)). Paired and unpaired variables were analysed with the Student's $t$ test. Linear correlations between individual $\mathrm{H}_{2}$ and $\mathrm{CH}_{4}$ results were calculated using the least square method. Differences were considered to be significant at the $p<0.05$ level.

\section{Results}

\section{$\mathrm{H}_{2}$ BREATH TEST}

Demographic characteristics of the subjects and results for the $\mathrm{H}_{2}$ breath test are summarised in the Table. Four subjects $(6 \cdot 1 \%)$ failed to produce significant amounts of breath $\mathrm{H}_{2}$ after $10 \mathrm{~g}$ lactulose administration $\left(\Delta \mathrm{H}_{2}<20 \mathrm{ppm}\right)$. They were all breath $\mathrm{CH}_{4}$ producers excreting large amounts of $\mathrm{CH}_{4}$ (mean $\mathrm{FBCH}_{4} 25 \cdot 2$ (12) ppm). Hence, breath $\mathrm{H}_{2}$ production was analysed in only 61 subjects $\left(25 \mathrm{CH}_{4}\right.$ non-producers, 36 producers).

Mean breath $\mathrm{H}_{2}$ concentrations in the control group and breath $\mathrm{CH}_{4}$ producers are shown in Figure 1 . No early $\mathrm{H}_{2}$ peak was observed in the 61 subjects; all values returned to basal concentrations during the 14 hour test period.

Mouth-to-caecum transit times are shown in Figure 2. Although there was considerable overlap between the individual values measured in the two groups, the mean mouth-to-caecum transit time was significantly longer $(p<0.005)$ in breath $\mathrm{CH}_{4}$ producers. In this latter group, 17 subjects were above the highest value observed in the controls. No statistically significant difference was observed according to sex or phase of the menstrual cycle. $\mathrm{H}_{2}$ production (AUC) was significantly lower in breath $\mathrm{CH}_{4}$ producers $(\mathbf{p}<0.05)$ than in the control group (Table).

\section{$\mathrm{CH}_{4}$ PRODUCTION}

In the $\mathrm{CH}_{4}$ producers, the mean $\mathrm{FBCH}_{4}$ concentration was $14.3(8 \cdot 3) \mathrm{ppm}$. The evolution of breath $\mathrm{CH}_{4}$ concentration observed in the two groups is shown in Figure 3.

Among the 36 breath $\mathrm{H}_{2}$ and $\mathrm{CH}_{4}$ producers, 30 subjects $(83 \%)$ showed an increase in $\mathrm{CH}_{4}$ production after lactulose had reached the 

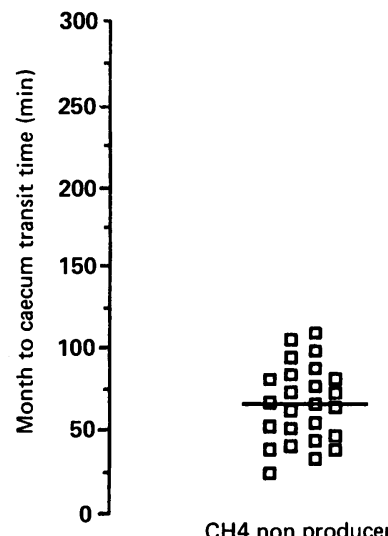

$\mathrm{CH} 4$ non producers

$\mathrm{CH} 4$ producers

Figure 2: Individual values of mouth-to-caecum transit time in $\mathrm{CH}_{4}$ non-producers $(n=25)$ and producers $\left(n=36 ; 4 \mathrm{CH}_{4}\right.$ producers not represented after failing to produce $\mathrm{H}_{2}$ ).

Horizontal lines indicate mean of each group. The intergroup difference was statistically significant $(p<0 \cdot 005)$.

caecum at the time ti. In these 30 subjects, the $\mathrm{CH}_{4}$ AUC was $0.4(0.5) 10^{3} \mathrm{ppm} / \mathrm{min}$ from lactulose administration (ti-mouth-to-caecum transit time) to ti and increased to $1 \cdot 1(0.9) 10^{3}$ $\mathrm{ppm} / \mathrm{min}$ from ti to ti+mouth-to-caecum transit time $(\mathrm{p}<0.0005)$.

In 11 breath $\mathrm{CH}_{4}$ producers $(27 \cdot 5 \%)$ a transient disappearance in $\mathrm{CH}_{4}$ production was observed, generally at the end of the test (mean 567 (180) $\mathrm{min}$ ). This decline was generally associated with a low level of $\mathrm{H}_{2}$ production.

Breath $\mathrm{CH}_{4}$ concentrations were always below $3 \mathrm{ppm}$ during the first 10 hours in control subjects; a delayed increase (Fig 3) occurred in 13 subjects $(52 \%)$, with no return to basal values during the experimental period.

CORRELATION BETWEEN BREATH $\mathrm{H}_{2}$ AND $\mathrm{CH}_{4}$ PRODUCTION

No significant correlation was found between the $\mathrm{H}_{2}$ AUC and either the whole $\mathrm{CH}_{4} \mathrm{AUC}(\mathrm{n}=40)$ or the $\mathrm{CH}_{4} \mathrm{AUC}$ after lactulose had reached the caecum $(n=36)$. Individual patterns of excretion curves for breath $\mathrm{H}_{2}$ and $\mathrm{CH}_{4}$ tended to be either that of a high $\mathrm{H}_{2}$ and low $\mathrm{CH}_{4}$ or that of a high $\mathrm{CH}_{4}$ and low $\mathrm{H}_{2}$. No subject was both a high $\mathrm{H}_{2}$ and high $\mathrm{CH}_{4}$ producer.

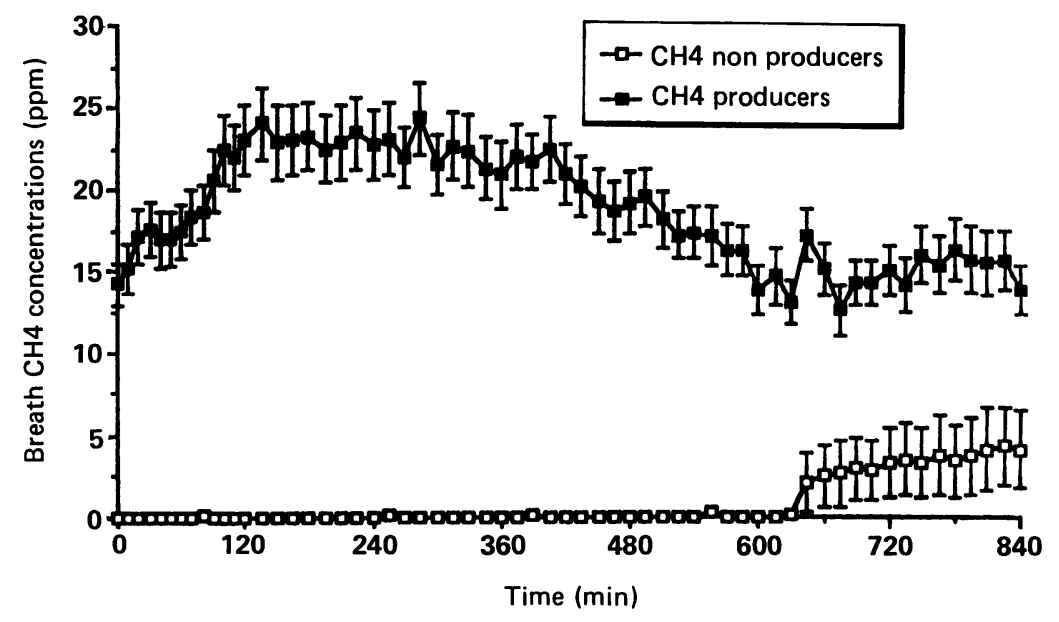

Figure 3: Breath $\mathrm{CH}_{4}$ concentrations (mean $(\mathrm{SEM})$ ) in $\mathrm{CH}_{4}$ non-producers $(n=25)$ and producers $(n=40)$ after oral administration of $10 \mathrm{~g}$ lactulose.

\section{Discussion}

While the definition of $\mathrm{CH}_{4}$ producing status dates back to the introduction of the breath test method, the criteria used to define a subject as a $\mathrm{CH}_{4}$ producer has varied considerably with time. Initially, Bond et $a l^{2}$ arbitrarily proposed that only those subjects with breath $\mathrm{CH}_{4}$ concentrations greater than $1 \mathrm{ppm}$ above atmospheric $\mathrm{CH}_{4}$ be designated as $\mathrm{CH}_{4}$ producers. A single breath sampling, however, may fail to detect an average of $18 \%$ of the breath $\mathrm{CH}_{4}$ producers in a given population. ${ }^{17}$ More recently, McKay et al ${ }^{19}$ have shown that all healthy subjects may produce $\mathrm{CH}_{4}$, though production of the gas appears in breath only after reaching a certain threshold. These investigators defined a $\mathrm{CH}_{4}$ producer as a subject emitting at least $2 \mathrm{ppm}$ above room air concentration, based on the sensitivity and reproducibility of the method used. In our study, the smallest detectable $\mathrm{CH}_{4}$ concentration was $2 \mathrm{ppm}$; thus, $\mathrm{CH}_{4}$ producers were defined as subjects producing mean $\mathrm{CH}_{4}$ concentrations after four breath samples of greater than $2 \mathrm{ppm}$ above those in ambient air.

$\mathrm{FBH}_{2}$ in our subjects was relatively low in comparison with levels found in a previous study. ${ }^{30}$ These results are, however, in agreement with data obtained by other investigators who showed that an evening meal containing a low level of indigestible carbohydrates before breath testing led to reduced $\mathrm{FBH}_{2}$ concentrations. ${ }^{2627}$ Like Bjorneklett and Jenssen, ${ }^{16}$ our breath $\mathrm{CH}_{4}$ producers showed lower $\mathrm{FBH}_{2}$ values than breath $\mathrm{CH}_{4}$ non-producers. Previous studies ${ }^{32}{ }^{33}$ have indicated that $\mathrm{FBH}_{2}$ measurements may be useful for the diagnosis of bacterial overgrowth and coeliac disease, but the influence of $\mathrm{CH}_{4}$ producing status was not examined.

Reports of the incidence of non- $\mathrm{H}_{2}$ producers range from $0 \%$ to $27 \%{ }^{162023}$ depending on the criteria used to define the absence of breath $\mathrm{H}_{2}$ production. Failure to produce breath $\mathrm{H}_{2}$ after the $10 \mathrm{~g}$ lactulose ingestion was infrequent in our population sample $(6 \cdot 1 \%)$. Here again, the definition of a breath $\mathrm{H}_{2}$ producer could explain these variations. For instance, in one recent study ${ }^{31}$ where ability to produce $\mathrm{H}_{2}$ was defined as an increase in breath $\mathrm{H}_{2}$ to greater than 20 ppm within four hours after ingestion of $10 \mathrm{~g}$ lactulose, $21 \%$ of subjects were found to be nonproducers. Upon using similar criteria, $15 \%$ of our $\mathrm{CH}_{4}$ producers would be non- $\mathrm{H}_{2}$ producers. This indicates that the lactulose breath test must be extended by at least six hours (Fig 2) as $\mathrm{H}_{2}$ increases of about $20 \mathrm{ppm}$ can occur with a delay, especially in $\mathrm{CH}_{4}$ producers. As in a previous study, ${ }^{16}$ we found that our four $\mathrm{H}_{2}$ nonproducers all excreted large amounts of $\mathrm{CH}_{4}$.

After ingestion of a meal, a so called early rise in breath $\mathrm{H}_{2}$ concentrations has been described ${ }^{34}$ with a subsequent return to basal level; this early peak thus precedes the actual peak caused by carbohydrate malabsorption. Various hypotheses have been proposed to explain this early increase. $\mathrm{H}_{2}$ production may be enhanced by the passage into the caecum of either ileal secretions or carbohydrates retained in the terminal ileum from a previous meal. ${ }^{34}$ Buccal fermentation, however, may well be a major determinant, with proper oral hygiene able to 
eliminate this phenomenon. ${ }^{28-30}$ In our study, the evening meal contained little indigestible material and attention was paid to meticulous oral hygiene. These two precautions were sufficient to eliminate the 'early peak'.

The $\mathrm{H}_{2}$ breath test is a simple, non-invasive method for measurement of mouth-to-caecum transit time, reflecting the arrival of the 'head' of the meal in the caecum. Although defined as the interval between meal ingestion and the detection of a significant and sustained rise in breath $\mathrm{H}_{2}$ excretion, ${ }^{+11}$ there is no uniformly accepted recommendation concerning either the threshold increase in $\mathrm{H}_{2}$ concentration or the dose of the lactulose load. Values of $10 \mathrm{ppm}$ and $10 \mathrm{~g}$, respectively, have been proposed by most investigators. ${ }^{36711}$ In one study, $\mathrm{CH}_{4}$ production was associated with slow colonic transit, ${ }^{35}$ but any apparent difference in mouth-to-caecum transit times between $\mathrm{CH}_{4}$ producers and nonproducers has previously not been reported. We are unable to explain this difference which may be related to lower $\mathrm{H}_{2}$ production and/or different patterns in gut motility. In order to assess the impact of sex on the study parameters, the same percentage of women in luteal and progestational phases was studied in each group. No significant difference in mouth-to-caecum transit times was noted between these phases.

Previous studies ${ }^{1314}$ suggest that malabsorption of carbohydrates can be quantified with reference to lactulose. In agreement with Bjorneklett and Jenssen ${ }^{16}$ using $33 \mathrm{~g}$ lactulose, our results showed a significant difference in breath $\mathrm{H}_{2}$ production between $\mathrm{CH}_{4}$ producers and non-producers after $10 \mathrm{~g}$ lactulose, but there was no correlation between breath $\mathrm{H}_{2}$ and $\mathrm{CH}_{4}$ production.

Breath $\mathrm{CH}_{4}$ production has rarely been examined over an extended time period. ${ }^{216}$ In this 14 hour trial, we observed that $83 \%$ of $\mathrm{CH}_{4}$ producers were able to excrete additional $\mathrm{CH}_{4}$ after ingestion of $10 \mathrm{~g}$ lactulose. This increase in $\mathrm{CH}_{4}$ has been observed previously with larger doses of lactulose. ${ }^{16} 1720$

The finding that breath $\mathrm{CH}_{4}$ may almost disappear rapidly in breath $\mathrm{CH}_{4}$ producers has been previously observed by Fritz and Siebert, though without explanation..$^{24}$ Our observation of late $\mathrm{CH}_{4}$ production in breath $\mathrm{CH}_{4}$ nonproducers has never been reported and might reflect modifications in colonic flora after 24 hour fasting.

Irrespective of the reasons for the observed differences between $\mathrm{CH}_{4}$ producers and nonproducers, these results appear clinically relevant. Indeed, ignoring these facts could lead to misinterpretation of mouth-to-caecum transit time in clinical practice or in the pharmacological assessment of prokinetic drugs. In the future, it is possible that determination of different thresholds of $\mathrm{H}_{2}$ concentrations for the calculation of mouth-to-caecum transit time may help solve the apparent discrepancies between $\mathrm{CH}_{4}$ producers and non-producers. For instance, in this study, the arrival of lactulose in the caecum was defined as a rise in the $\mathrm{H}_{2}$ concentration of at least $10 \mathrm{ppm}$. Hence, at 70 minutes (mouth-to-caecum transit time in controls), the mean $\mathrm{H}_{2}$ concentration was $18 \mathrm{ppm}$
$\left(\mathrm{FBH}_{2}=8 \mathrm{ppm}+10 \mathrm{ppm}\right)$. The corresponding increase in $\mathrm{H}_{2}$ for $\mathrm{CH}_{4}$, producers was $5 \mathrm{ppm}$ ( 10 $\mathrm{ppm}-\mathrm{FBH}_{2}=5 \mathrm{ppm}$ ) (Fig 1). Therefore, it is possible that thresholds for the detection of lactulose in the caecum may have to be revised in accordance with $\mathrm{CH}_{4}$ producing status. This approach would in fact require the use of a different method for the measurement of mouthto-caecum transit time not based on $\mathrm{H}_{2}$ production by colonic flora. Until new thresholds of $\mathrm{H}_{2}$ concentrations are validated, we suggest limiting the use of the $\mathrm{H}_{2}$ breath test to intra-individual comparisons (crossover design) after stratification of $\mathrm{CH}_{4}$ producers and non-producers. The same restrictions apply to quantification of carbohydrate malabsorption in physiopathological studies.

We are grateful to $\mathrm{Mr}$ and Mrs F Shapiro (Syntaxis-Belgium) for editorial assistance with this manuscript.

1 Bond JH, Levitt MD. Use of pulmonary hydrogen $\left(\mathrm{H}_{2}\right)$ measurements to quantitate carbohydrate absorption. $\mathcal{F}$ Clin Invest 1972; 51: 1219-25.

2 Bond JH, Engel RR, Levitt MD. Factors influencing pulmonary methane excretion in man. $\mathcal{F}$ Exp Med $1971 ; 133$ : 572-88.

3 Solomons NW. Evaluation of carbohydrate absorption: the hydrogen breath test in clinical practice. Clin Nutr 1984; 3 71-8.

4 Bond JH, Levitt MD. Investigation of small bowel transit time in man utilising pulmonary hydrogen $(\mathrm{H} 2)$ measurements. in $\mathrm{Lab}$ Clin Med $1975 ; 85: 546-55$.

5 Solomons N, Vasquez L, Torun B, Viteri F. A non-invasive methodology for mouth-to-colon transit time determination in pre-school children using hydrogen $(\mathrm{H} 2)$ breath analysis in pre-school children using hydrogen (H2)

6 Corbett CL, Thomas S, Read NW, Hobson N, Bergman I, Holdsworth CD. Electrochemical detector for breath hydrogen determination: measurement of small bowel transit in normal subjects and in patients with the irritable bowel syndrome. Gut 1981; 22: 836-40.

7 La Brooy SJ, Male PJ, Beavis AK, Misiewicz JJ. Assessmen of the reproducibility of the lactulose $\mathrm{H} 2$ breath test as a measure of mouth to caecum transit time. Gut 1983; 24 me3-6.

8 Campbell FC, Cuschieri A. Critical rise in breath hydrogen in evaluation of intestinal transit [Abstract]. Gut 1986; 27 A1270.

9 Caride VJ, Prokop EK, Troncale FJ, Buddoura W, Winchenbach K, McCallum RW. Scintigraphic determination of small intestinal transit time: comparison with the tion of small intestinal transit time: comparison with the
hydrogen breath technique. Gastroenterology 1984; 86: 714 20.

10 Kellow JE, Borody TJ, Phillips SF, Haddad AC, Brown ML. Sulfapyridine appearance in plasma after salicylazosulfapyridine. Another simple measure of intestinal transit. Gastroenterology 1986; 91: 396-400.

11 Wald A, Van Thiel DH, Hoechstetter L, et al. Gastrointestinal transit: the effect of the menstrual cycle. Gastroenterolog 1981; 80: 1497-500.

12 Basilisco G, Bozzani A, Camboni G, et al. Effect of loperamide and naloxone on mouth-to-caecum transit time evaluated by lactulose hydrogen breath test. Gut 1985; 26: 700-3.

13 Levitt MD, Hirsh P, Fetzer CA, Sheahan M, Levine AS. H2 excretion after ingestion of complex carbohydrates. Gastroenterology 1987; 92: 383-9.

14 Flourié B, Florent C, Evard D, Jouany JP, Thivend P Rambaud JC. Evaluation in man of lactulose hydrogen (H2) breath test, to quantitate starch delivered in the colon [Abstract]. Gastroenterology 1983; 84: 1155.

15 Calloway DH. Respiratory hydrogen and methane as affected by consumption of gas-forming foods. Gastroenterology 1966 51: 383-9.

16 Bjorneklett A, Jenssen E. Relationships between hydrogen (H2) and methane (CH4) production in man. Scand $f$ Gastroenterol 1982; 17: 985-92.

17 Pitt P, De Bruijn KM, Beeching MF, Goldberg E, Blendis LM. Studies on breath methane: the effect of ethnic origins and lactulose. Gut 1980; 21: 951-9.

18 Piqué JM, Pallarés M, Cuso E, Vilar-Bonet J, Gassull MA. Methane production and colon cancer. Gastroenterolog Methane producti

19 Mckay LF, Eastwood MA, Brydon WG. Methane excretion in man a study of breath, flatus and faeces. Gut 1985; 26: 6974.

20 Flatz G, Czeizel A, Métneki J, Flatz SD, Kühnau W, Jahn D. Pulmonary hydrogen and methane excretion following ingestion of an unabsorbable carbohydrate: a study of twins. $\mathcal{F}$ Pediatr Gastroenterol Nutr 1985; 4: 936-41

21 Peled Y, Weinberg D, Hallak A, Gilat T. Factors affecting methane production in humans. Dig Dis Sci 1987; 32: 267 71. 
22 Segal I, Walker ARP, Lord S, Cummings JH. Breath methane and large bowel cancer tions. Gut 1988; 29: 608-13.

23 Cloarec D, Bornet F, Barry JL, Colonna P, Gouilloud S, Galmiche JP. Starch malabsorption in healthy subjects [Abstract]. Gastroenterology 1988; 94: A72.

24 Fritz M, Siebert G. Dose dependence of breath hydrogen and methane in healthy volunteers after ingestion of a com-
mercial disaccharide mixture, Palatinit. Br f Nutr 1985; 54: mercial disac

25 Gilat T, Ben Hur H, Gelman-Malachi E, Terdiman R, Peled $\mathrm{Y}$. Alterations of the colonic flora and their effect on the hydrogen breath test. Gut 1978; 19: 602-5.

26 Kotler DP, Holt PR, Rosenweig NS. Modification of the breath hydrogen test: increased sensitivity for the detection of carbohydrate malabsorption. F Lab Clin Med 1982; 100: 798-805.

27 Brummer RJM, Armbrecht U, Bosaeus I, Dotevall G Stockbruegger RW. The hydrogen (H2) breath test. Scand $\mathcal{f}$ Gastroenterol 1985; 20: 1007-13.

28 Thompson DG, Binfield P, De Belder A, O'brien J, Warren S, Wilson $M$. Extra intestinal influences on exhaled breath hydrogen measurements during the investigation of gastro- intestinal disease. Gut 1985; 26: 1349-52.

29 Thompson DG, O'Brien JD, Hardie JM. Influence of the oropharyngeal microflora on the measurement of exhaled breath hydrogen. Gastroenterology 1986;91: 853-60.

30 Mastropaolo G, Rees WDW. Evaluation of the hydrogen breath test in man: definition and elimination of the early breath test in man: definition and

31 Saltzberg DM, Levine MG, Lubar C. Impact of age, sex, race, and functional complaints on hydrogen $(\mathrm{H} 2)$ production. Dig Dis Sci 1988; 33: 308-13.

32 Perman JA, Modler S, Barr RG, Rosenthal P. Fasting breath hydrogen concentration: normal values and clinical application. Gastroenterology 1984; 87: 1358-63.

33 Corazza GR, Strocchi A, Gasbarrini G. Fasting breath hydrogen in celiac disease. Gastroenterology 1987; 93: 53-8.

34 Read NW, Al-Janabi MN, Bates TE, et al. Interpretation of the breath hydrogen profile obtained after ingesting a solid meal containing unabsorbable carbohydrate. Gut 1985; 26 : $834-42$.

35 Stephen AM, Wiggins HS, Englyst HN, Cole TJ, Wayman BJ, Cummings JH. The effect of age, sex and level of intake of dietary fibre from wheat on large bowel function in thirty healthy subjects. Br f Nutr 1986; 56: 349-61. 